\title{
Material choices for fibre in the neolithic: an approach through the measurement of mechanical properties
}

DOI:

10.1111/arcm.12267

\section{Document Version}

Accepted author manuscript

Link to publication record in Manchester Research Explorer

\section{Citation for published version (APA):}

Harris, S., Haigh, S., Handley, A., \& Sampson, W. (2016). Material choices for fibre in the neolithic: an approach through the measurement of mechanical properties. Archaeometry. https://doi.org/10.1111/arcm.12267

\section{Published in:}

Archaeometry

\section{Citing this paper}

Please note that where the full-text provided on Manchester Research Explorer is the Author Accepted Manuscript or Proof version this may differ from the final Published version. If citing, it is advised that you check and use the publisher's definitive version.

\section{General rights}

Copyright and moral rights for the publications made accessible in the Research Explorer are retained by the authors and/or other copyright owners and it is a condition of accessing publications that users recognise and abide by the legal requirements associated with these rights.

\section{Takedown policy}

If you believe that this document breaches copyright please refer to the University of Manchester's Takedown Procedures [http://man.ac.uk/04Y6Bo] or contact uml.scholarlycommunications@manchester.ac.uk providing relevant details, so we can investigate your claim.

\section{OPEN ACCESS}




\title{
MATERIAL CHOICES FOR FIBRE IN THE NEOLITHIC:AN APPROACH THROUGH THE MEASUREMENT OF MECHANICAL PROPERTIES*
}

\author{
S. HARRIS $\dagger$ \\ Archaeology, School of Humanities, University of Glasgow, Lilybank Gardens, Glasgow G12 8QQ, UK
}

S. HAIGH

School of Materials, Manchester University, Oxford Road, Manchester M13 9PL, UK

\section{A. HANDLEY}

School of Materials, Manchester University, Oxford Road, Manchester M13 9PL, UK

and W. SAMPSON

School of Materials, Manchester University, Oxford Road, Manchester M13 9PL, UK

\begin{abstract}
Studies of the Mesolithic-Neolithic transition in Europe have focused on plants and animals exploited for food. However, the exploitation of plants for fibres underwent a significant change with the addition of domestic flax as a fibre crop. While the technology of flax fibre processing is increasingly understood by archaeologists, its material value as a fibre crop in comparison to indigenous fibre is less well explored. We examine the mechanical properties of flax and two indigenous fibres (lime bast, willow bast), by testing fibre strips for tensile properties and discuss the results in the light of material choices in these periods.
\end{abstract}

KEYWORDS: MESOLITHIC-NEOLITHIC TRANSITION, MATERIAL PROPERTIES, FIBRE, FLAX, LIME, WILLOW, TEXTILES

\section{INTRODUCTION}

As one of the major horizons of change in European prehistory, the Mesolithic-Neolithic transition has been extensively studied (recently by Bickle and Whittle 2014). The nature of this transition is defined by the introduction of domesticated plants and animals and their role in agriculture. While archaeologists have debated the reasons and effect of these changes (see overviews by Barker 2006, 1-38; Robinson et al. 2011), the focus of research has been mostly on food resources and their role in diet. However, plants and animals are also a source of materials and Neolithic/Mesolithic communities procured plant fibres for their tying, binding and fibrous cloth needs (Hardy 2008; Hurcombe 2014, 36-42). The Neolithic in Europe saw a major change in the source of plant fibres with the introduction of flax as a domesticated fibre plant from south-west Asia (Zohary et al. 2012, 103-6), which was used alongside indigenous plant fibres such as tree bast, which is extracted from the inner bark of certain trees, and fibres of other indigenous plant species. 
This changing picture of plant fibre resources does not just represent a different mode of subsistence or technology of production by early farmers, but a whole new material, the properties of which could have been understood through experience and experimentation. When considering the role of fibres in the Neolithic, this raises the question: why did early farmers choose to grow flax for fibre? Was it because flax fibres provided an especially good material that was superior to alternative fibres? In this paper, we address this question from a materials perspective through measuring the mechanical properties of flax, lime and willow bast fibres. In the light of the many variables affecting natural fibre properties, this constitutes an initial study and further factors influencing fibre properties are considered in the discussion.

The recent materialist turn in archaeology, with its schools of thought around materials, materiality, material agency and symmetrical archaeology, stems from an epistemological desire to understand the complex relationship between people and things. Within this debate is the investigation of archaeological materials through their material properties. This has been proposed in different veins by Jones in his paper 'Archaeometry and materiality' (2004) and by Ingold's 'Materials against materiality' (2007), both of which have been criticized (e.g., there have been responses to both papers). As Lucas observes, Ingold and Jones are attacked for their physical view of materiality, their attention to 'brute matter', for holding a vulgar notion of physicality and, with it, accusations that this separates mind and matter, nature and culture (Lucas 2012, 162-4). While justified, Lucas also notes, archaeologists face difficulty in marrying physical and social concepts of materiality.

To reject the physicality of matter is counterproductive to investigating materials, as this is part of the choices people face as they transform materials into objects, which in turn affects the relationships that people have with objects (Sillar and Tite 2000, 6-8, fig.1). As recognized in textile technology, fibre is the smallest unit of finished products, such as thread, cord or textile, and is its primary material (Collier and Tortora 2001, 29, 47). Hence fibre properties influence the characteristics of these products, whether mechanical, aesthetic or sensory, and in turn the ideological, political and social aspects that these engender. Archaeologists are frequently dealing with uncommon materials (e.g., lime bast and willow bast) that few non-specialists have encountered. A range of perspectives, including one of physical matter, is required to consider a material's role in the past. The purpose of this study is to add new quantitative, comparative data (of flax and two species of tree bast) to this literature and through this question the material choices provided by these fibres, and hence the relationship between people and fibres in the Mesolithic and Neolithic.

An understanding of fibres is not helped by the nature of the archaeological record, as when ancient fibre artefacts such as threads, cords, rope, textiles and basketry are excavated they are fragile, degraded and no longer retain their original material properties. For this reason, mechanical testing in this experiment was carried out on modern fibre strips of the same species (Fig. 1). Furthermore, commercial fibres used in the modern textile or craft industry are industrially processed to speed up and stabilize the process and remove all extraneous plant matter (Jarman 1998, 17). In this experiment, the plant materials were processed by hand, using methods appropriate to Mesolithic and Neolithic technological contexts. Modern examples of these fibres prepared as fibre strips are here tested for tensile properties: Young's modulus, ultimate tensile strength and toughness. These tests characterize the elasticity, strength and amount of energy required to deform and break the materials. The value of mechanical testing is that it provides objective, quantifiable and comparable results, and may be used to predict the performance of materials (Saville 1999, 3). 


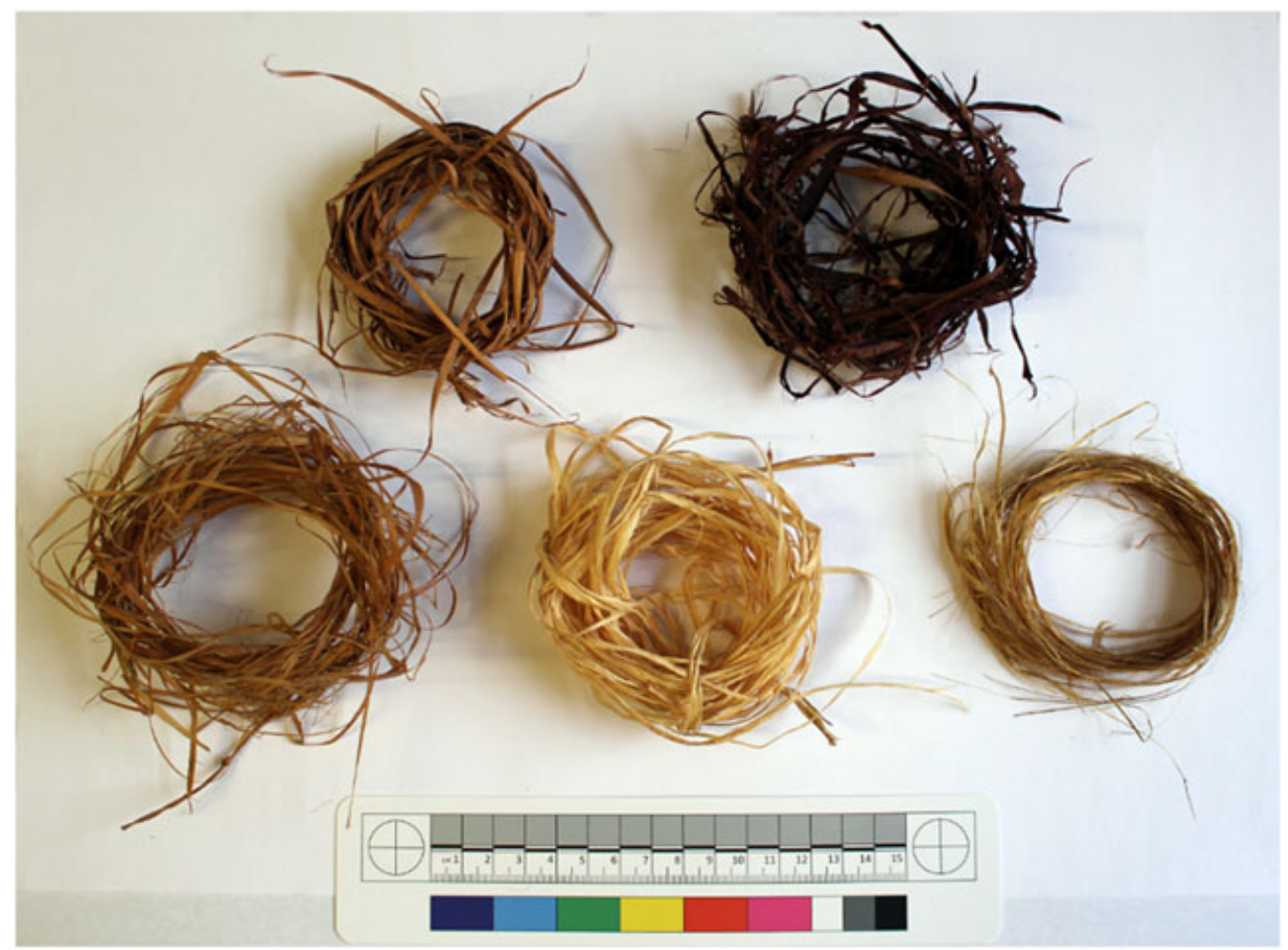

Figure 1 Fibres tested: clockwise from bottom left: lime bast, willow bast, willow bast boiled, flax and raffia (photograph by S. Harris, colour image available online).

\section{PLANT FIBRES IN THE MESOLITHIC AND NEOLITHIC}

\section{Resources}

Bast fibre is the term given to those fibres extracted from plant stems, whether annual plants or the inner bark of trees. This experiment was set up to study the mechanical properties of bast fibres of flax, lime and willow processed using two methods. These are three of the most commonly identified fibre species from Mesolithic and Neolithic contexts.

\section{Flax}

While taphonomic processes make Neolithic fibres difficult to study, recent research has refined questions around the domestication of flax (Allaby et al. 2005), flax processing technology (Herbig and Maier 2011; Leuzinger and Rast-Eicher 2011; Maier and Schlichtherle 2011) and the chronology of flax cultivation in Europe and South-West Asia (Karg 2011a; Zohary et al. 2012, 103-6). Along with other domestic crops, flax was one of the founder crops of the Early Neolithic, originating in South-West Asia (Zohary et al. 2012, 104) and was the earliest cultivated fibre plant in Europe. Discounting claims for Palaeolithic flax fibres (Kvavadze et al. 2009) on the basis of the points outlined by Bergfjord et al. (2010), the earliest preserved identified linen threads and cloth are found in South-West Asia; for example, at Nahal 
Hemar, a desert cave in Israel, from which a twined cloth is radiocarbon-dated to $7065 \mathrm{cal}$. BC $(8500 \pm 220$ BC with 95.4\% certainty: OxA 1015, calibrated with OxCal 4.2) (Schick 1988, 31). In Europe, besides scattered finds, the largest concentrations of fibrous artefacts are from the waterlogged Late Neolithic lake settlements and wetland sites of the Circum-Alpine area (c.4200-2800 cal. BC) and include threads, cords, nets and textiles made from flax and tree bast (see, e.g., Rast-Eicher 1997, 2005; Körber-Grohne and Feldtkeller 1998; Leuzinger 2002; Bazzanella et al. 2003; Bazzanella and Mayr 2009; Médard 2010; Karg 2011b) (Figs 2 (a) and 2 (b)). This is several thousand years later than the earliest preserved flax seeds in the Alpine region and Central Europe, which date to the end of the seventh and sixth millennia BC (Rast-Eicher 2005, 119). This highlights a problematic lacuna in evidence.

\section{Tree bast}

Knowledge of the species exploited for indigenous plant fibres rests on the identification of preserved fibres, as tools are rarely associated with these fibres and archaeobotanical remains are insufficient evidence for fibre extraction. Tree bast fibre artefacts only survive in favourable conditions, such as dry, cold or waterlogged environments. Preserved threads, cords, nets and looped cloth from Late Mesolithic contexts in Northern Europe provide rare evidence for the raw materials used by hunter-gatherers for plant fibres. Of these tree bast fibres, from the inner bark of certain species of trees, and grasses were a key resource. Willow (Salix sp.), possibly poplar bast (Populus sp.) and grasses (Gramineae) are identified in looped cloth, cords and fish nets from submerged Mesolithic sites in Scandinavia and around the Baltic (c. 4200-3400 cal. BC) (Bender Jørgensen 1990, 2; Burov 1998, 58-62; Andersen 2013, 215-16). In the Late Neolithic Swiss lake dwellings, tree bast fibres were of lime, oak and willow (Médard 2010, 57). These trees are part of the indigenous, deciduous forests of Europe (Greig 1982, 23).

(a)

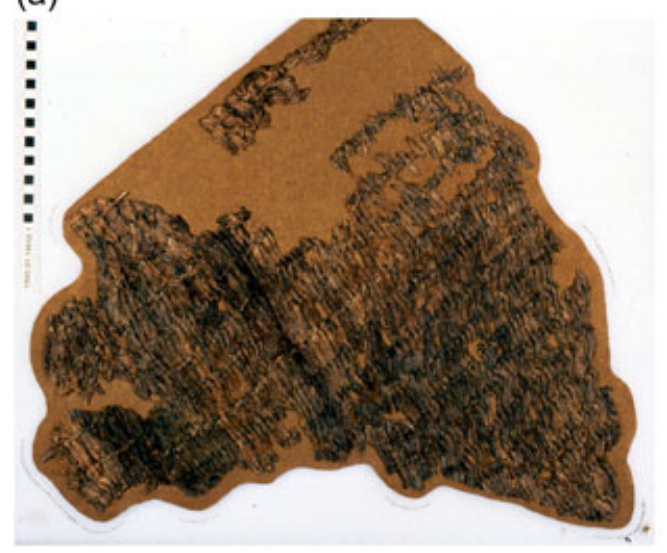

(b)

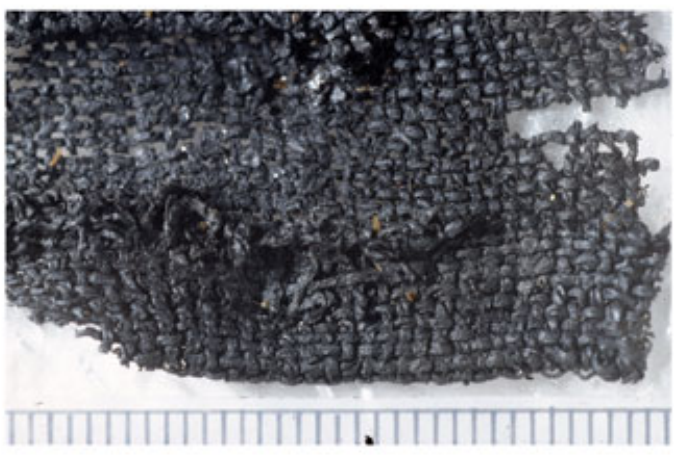

Figure 2 Twined cloth in lime bast (Tilia sp.) from Arbon Bleiche 3, Switzerland, dendrochronology dated to 3384-3370 cal. BC. Thread diameter in passive element $3 \mathrm{~mm}$; scale in cm. (b) Textile, most probably linen (Linum sp.), from Arbon Bleiche 3, Switzerland. Scale in mm (photographs by Amt für Archäologie Thurgau, www. archaeologie.tg.ch, Daniel Steiner). 


\section{Other plant fibres}

It is possible that bast from other plants was used for fibres, although at present few of these species have been identified in Mesolithic or Neolithic artefacts. This is potentially an issue of preservation and identification. Bulrush fibres are identified at Zamostje 2, a Mesolithic to Neolithic site in Russia (Lozovskaya et al. 2012). Other indigenous fibrous plants that could have been exploited for fibres, fibrous leaves or stems include, but are not limited to: wild clematis (Clematis vitalba), bramble (Rubus fruticosus), honeysuckle (Lonicera L.), moss (Polytrichum commune), flag iris (Iris pseudacorus), cat tail or reedmace (Typha sp.), club rush (Scirpus lacustris), soft rush (Juncus effuses) and nettle (Urtica dioica) (Hurcombe 2007, 122; Wood 2011, 13; Médard 2012, 368; Harris and Gleba 2015). Reeds, virburnum and grasses were used as whole stems (Rast-Eicher 1997, 302). Nettles are assumed to have been exploited for fibre in the Mesolithic and Neolithic due to the abundance of seeds and mention in ethnobotanical sources (e.g., Van Gijn 2010, 63, 85; Hurcombe 2014, 55-7, 63). However, nettle is not included in this study, as the authors know of no Mesolithic or Neolithic fibre artefacts identified as nettle; the earliest identified nettle fibres are from the Bronze Age (Barber 1991, 19-20; Farke 1991; Bergfjord et al. 2012). Wool from domestic sheep was only used for textiles from the mid-fourth millennium BC in South-West Asia, and substantially later in many areas of Europe, and is therefore of later chronological concern.

\section{PROCESSING}

Plants (annuals or trees) require processing to extract the bast fibres following a range of techniques. It is often difficult to ascertain the exact methods used to process fibres in the past.

\section{Flax}

For many decades, it was assumed that in prehistory flax stems were processed for fibre according to the techniques of rotting (retting), beating (breaking), scraping (scutching) and combing (heckling) (Barber 1991, 13-14; Martial and Médard 2007, 70-4). These processes were historically widespread in Europe and beyond (Jarman 1998, 10-19). Retting softens the fibres and rots the connective tissues of the plant matrix. Beating breaks the inner core of the stem, while the combination of beating, pounding, scraping and combing acts to remove the unwanted tissues and inner core, as well as to separate out the fibres. Historically, and in small-scale production in the present day, the techniques and combination of processes can vary. Retting, for example, may be achieved when whole stems are submerged in pits, in natural water (fresh, brackish and salt) or are left to lie in the fields, where the action of dew rets the stems (Jarman 1998, 10-19).

Observation of preserved flax fibres used to make threads and textiles in prehistoric Europe suggests that the plants may have been processed differently. Microscopic investigations of Neolithic flax fibre products from the lake dwellings demonstrate less thorough processing: extraneous plant matter is left on the fibres, and fibres remain in bundles (Körber-Grohne and Feldtkeller 1998, 153; Rast-Eicher and Thijsser 2001; Leuzinger and Rast-Eicher 2011, 537, 540; Maier and Schlichtherle 2011, 569-70). It seems likely that flax was processed with a light ret before the fibres were stripped from the stem (Leuzinger and Rast-Eicher 2011, 538-9). 


\section{Tree bast}

Methods of tree bast processing are understood from ethnographic sources, especially from Scandinavia, the Baltic countries, Russia and Central Europe where, historically, lime bast was an important fibre for rope and cord making (Warnford Lock and Stab 1880, 916-17; Hanssen and Lundestad 1932; Granlund 1943-4; Dimbleby 1978; Hodges 1995, 127; Crawford 2005; Myking et al. 2005, 66-9; Pigott 2012, 350; Hurcombe 2014, 30). These sources report four methods of processing lime bast. (1) Branches are removed from the trees in early summer, just as the leaves grow to full size. Either the whole branches or stripped bark are then soaked in fresh or sea water for several weeks (retting), which softens the bast and causes the separation of individual fibrous layers. (2) Bark is removed earlier in the year when the sap is rising in the tree, in which case the bast can be separated directly from the outer bark. (3) Trees are cut in winter and the branches smoked in an oven for a full day. In the second and third methods, no retting is involved: the fibres are directly processed and remain stiffer than the retted fibres gained in the first method. (4) Stems or inner bark are boiled in a wood ash solution (weak alkali) to separate the fibres.

These techniques are reported as potential methods used in the past (Rast-Eicher 1997, 302-3; Körber-Grohne and Feldtkeller 1998, 157; Reichert 2000, 2007; Médard 2003, 82). It remains difficult to ascertain the exact method of processing tree bast from the archaeological evidence. For example, threads, cords and textiles that are washed or used in wet environments continue to slowly rot throughout their use-life (Hero Granger-Taylor pers. Comm.) and may appear more thoroughly retted than was originally the case. Tools are poor indicators of tree bast processing. Use-wear analysis on Neolithic stone tools suggests that they were used to scrape plant fibres from dried stems (Van Gijn 2010, 87-8). Similarly, Neolithic bone tools may be associated with removing bark from trees (Médard 2003, 82).

\section{PROPERTIES}

The study of the mechanical properties of materials is a developed area of materials science. Most research into plant fibres concentrates on those fibres with commercial value, such as flax (e.g., Kornreich 1952; Needles 1981; Puliti 1987; Airoldi 2000; Wulfhorst 2001; Norton et al. 2006). Tree bast has been less frequently studied. In terms of quantitative analysis, a recent forestry report focused on the mechanical properties of a $12 \mathrm{~mm}$ three-ply cord of lime bast (Troset and Aunrønning 2003, reported in Myking et al. 2005) Pigott quotes stress at break for a strand of Tilia cordata of $4.5 \mathrm{~kg} \mathrm{~mm}^{-2}\left(44 \mathrm{~N} \mathrm{~mm}^{-2}\right)$, although with no reference to the source or methods (Pigott 2012, 29-30). Ethnographic, historical and archaeological reports provide a qualitative approach to the mechanical properties of tree bast (Hanssen and Lundestad 1932; Granlund 1943-4; Dimbleby 1978; Rast-Eicher 1997, 303; Médard 2003, 2010, 145; Reichert 2007, 2011, 2013; Harris 2010; Wood 2011, 12-14; Pigott 2012; Hurcombe 2014, 30). Historical records record the suitability of tree bast fibres for tasks; for example, lime bast rope in medieval shipping, and sacks, shoes and sails in 18th to mid-19th century Russia and the Baltic (Körber-Grohne and Feldtkeller 1998, 156-7; McGrail 2014, 204-51).

\section{MATERIALS}

We begin by clarifying the archaeological use of the term 'fibre'. In the textile industry, fibre refers to the long, fine, flexible units that form the basis of textiles that have a high ratio of length to thickness (Greaves and Saville 1995, 1). Typically, they are considered to have a length at least 
100 times their diameter (Collier et al. 2009, 4). For materials scientists, there remains an expectation that a fibre will be $100 \mu \mathrm{m}$ or less in diameter. For archaeologists working with textiles, the term fibre refers to long, pliable raw materials that can be worked into thread and fabric (Gleba and Mannering 2012, 5). This frequently refers to materials that are several millimetres in width and hundreds of millimetres in length. These are not fibres in the textile or materials science sense, in that they include fibre bundles and extraneous plant matter; they are better described as fibre strips. In this experiment, we work with fibre strips, as this was deemed appropriate according to methods used to process fibres in the Mesolithic and Neolithic, as discussed above. We refer to our samples as fibre strips.

Following the observations described above, that flax fibres appear to be less thoroughly processed in the Neolithic than in the present day, the flax fibres in our experiment were removed from the dried, unretted stem in strips that were harvested in September when the seeds were ripe (Table 1). This is an important distinction for the tests carried out in this experiment, as it is frequently the single fibres of annual plants that are tested for mechanical properties in the commercial literature (e.g., Bodros and Baley 2008, 2143-4), or those mechanically processed fibres (e.g., Norton et al. 2006, 17), whereas we are interested in the fibre strips. The extent to which flax was retted in the past is unclear; here, we chose to leave the fibres unretted.

The lime bast was extracted by removing the bark from the wood in July. The bark was water retted for 6 weeks, then separated into single-layer strips that were then dried and split into finer fibres (Table 1). The willow bast was processed using two methods. Once the bark was removed in June, it was dew retted for 2 months: half was stripped while dew-damp, while the other half was boiled in a weak alkali solution. We tested commercially purchased raffia to provide a commonly available comparative example.

\section{METHOD: MECHANICAL PROPERTY MEASUREMENTS}

The fibres, prepared in strips, were tested for their tensile properties: Young's modulus, ultimate tensile strength and toughness. Such plant materials are naturally inhomogeneous, so 10 tests were performed for each sample, on 10 separate fibre strips of the same processed batch. The materials were tested under wet and dry conditions.

Tensile testing of the fibre strips was performed using an Instron Universal Tensile Testing Machine in the laboratory at the School of Materials, Manchester University, which is maintained at a constant temperature and humidity. In preparation for testing, 10 fibre strips of each sample were cut into fixed $100 \mathrm{~mm}$ lengths. The width of each fibre strip was recorded in millimetres and the thickness measured using a micrometer. The mass of each fibre strip was measured in grams using a balance. As these natural fibres are inhomogeneous, multiple tests must be carried out to gain a statistically reliable result (Saville 1999, 18). In these tests, 10 fibre strips were tested for each fibre. Each fibre strip was placed in the Tensile Tester with an initial distance of $50 \mathrm{~mm}$ between the grips, and a continuous force was applied to stretch the fibre strip to failure. The tests were carried out according to standard procedures (see Saville 1999, 115-67) and the force-distance curves recorded for each sample. From these force-distance curves, it is straightforward to determine the Young's modulus, ultimate tensile strength and toughness of the fibre strip, as discussed briefly below.

The properties of fibres, especially natural fibres, can be strongly affected by moisture content, including atmospheric moisture content (Saville 1999, 26-8). The fibre strips were therefore tested under wet and dry conditions. The fibre strips tested in the 'dry' condition were measured after storage in the same humidity-controlled room as used for testing for more than 24 hours. 


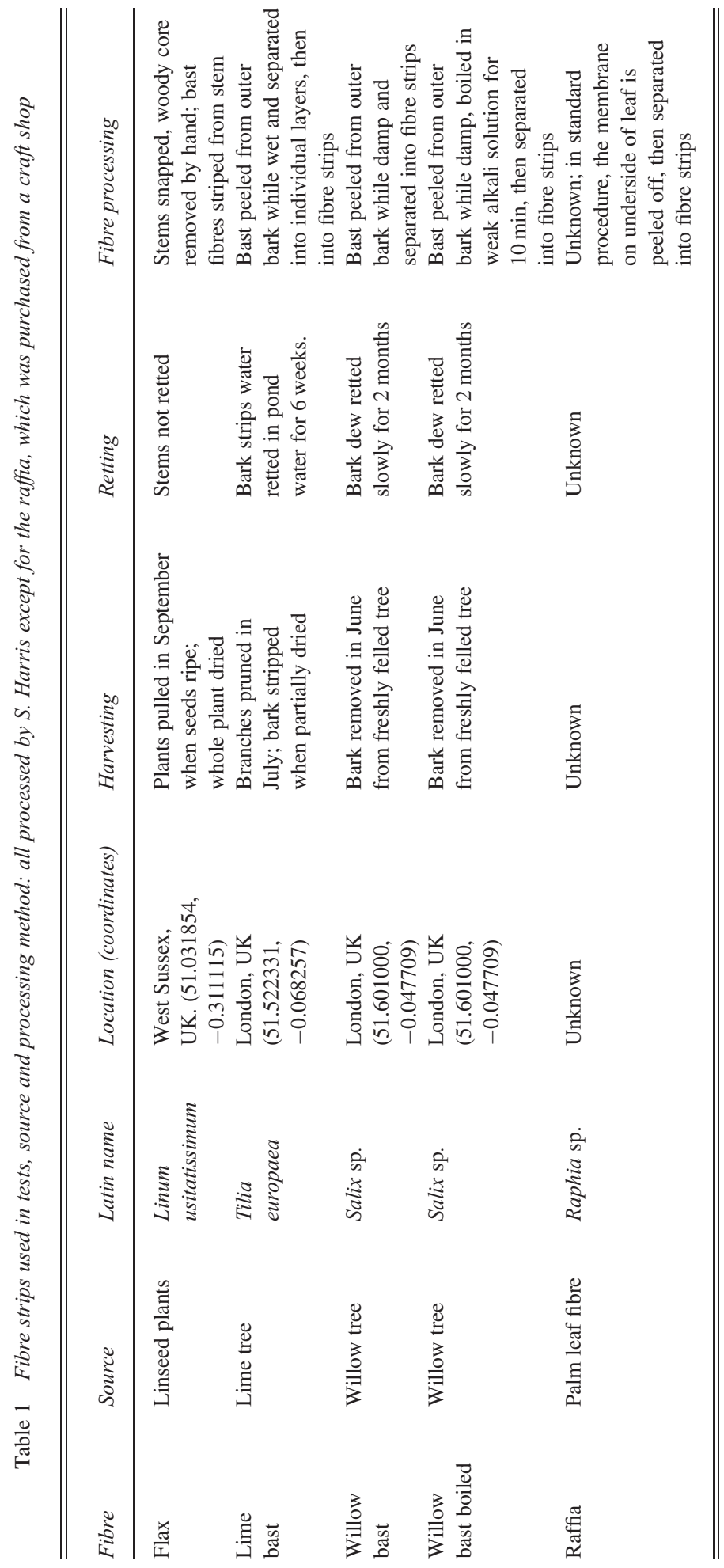


The 'wet' condition samples were soaked in water for 5 days. Each 'wet' tested sample was taken out of the liquid immediately prior to tensile testing, with excess liquid being removed using an absorbent blotter.

\section{Young's modulus}

Young's modulus (also known as the tensile modulus or elastic modulus) refers to how much the fibre will stretch elastically (deform) when a tensile force is applied. It therefore measures the resistance to extension; in other words, the stiffness of the material (Saville 1999, 122). Young's modulus is measured in gigapascals $\left(\mathrm{GPa}\right.$ or $\left.\mathrm{kN} \mathrm{mm}^{-2}\right)$. A fibre with a low resistance will stretch considerably when a low force is applied; for example, a rubber band has a low Young's modulus (Collier and Tortora 2001, 53). Materials with a high modulus tend to be brittle (i.e., stiff) regardless of tensile strength. The amount by which a fibre stretches or deforms is important, as materials are usually used well below their breaking point. The Young's modulus is determined from the gradient of a straight line in the steep elastic (low-elongation) region of the force-distance curve (below the yield point).

\section{Ultimate tensile strength}

Generally described as the strength of a fibre, the ultimate tensile strength can also be referred to as the breaking strength or tensile strength at break. It is the 'maximum tensile force recorded in extending a test piece to breaking point' (Saville 1999, 116). Ultimate tensile strength is measured in megapascals (MPa). Breaking force is proportional to cross-sectional area; so although a spider's web is one of the strongest fibres, it breaks more easily than a human hair on account of its lower diameter (Collier and Tortora 2001, 52). Normalizing the breaking force for each fibre by its cross-sectional area gives the ultimate tensile strength.

\section{Toughness}

Toughness measures the amount of work required to break the material and can be calculated from the area under the force-distance curve. Toughness is measured in joules per cubic metre $\left(\mathrm{J} \mathrm{m}^{-3}\right)$. In practice, toughness measures the ability of the material to absorb energy and withstand shocks before catastrophic failure. This is particularly important for situations where sudden shock may occur, such as with car seat belts or climbing ropes (Saville 1999, 127).

\section{RESULTS}

The measured values for the Young's modulus, ultimate tensile strength and toughness for the fibre strips measured are shown in Figures 3-5 below. The error bars represent 95\% confidence intervals and indicate the range of the results across the 10 repeats. Despite the issue that processing is likely to affect the properties of the fibre strips, variation between differently processed willow bast fibre strips was minimal in these tests. The greater differences were observed between species.

\section{Fibre strip Young's modulus}

The measurements for the Young's modulus of the fibre strips, measured in the wet and dry conditions (lime bast, willow bast, willow bast boiled, raffia and flax) are presented in Figure 3. Dry flax has the highest modulus $(18 \mathrm{GPa})$, showing that it has the stiffest fibre strips, although 


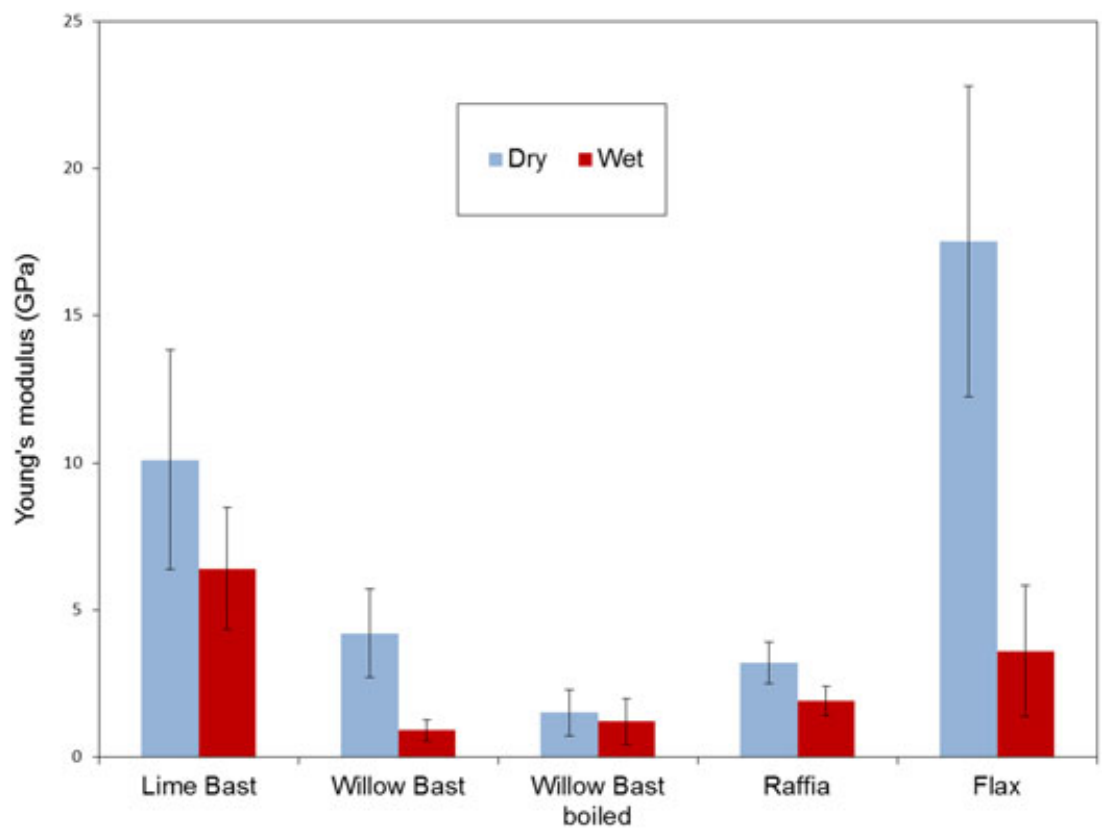

Figure 3 A comparison of the Young's modulus for the different fibres tested in 'dry' and 'wet' conditions.

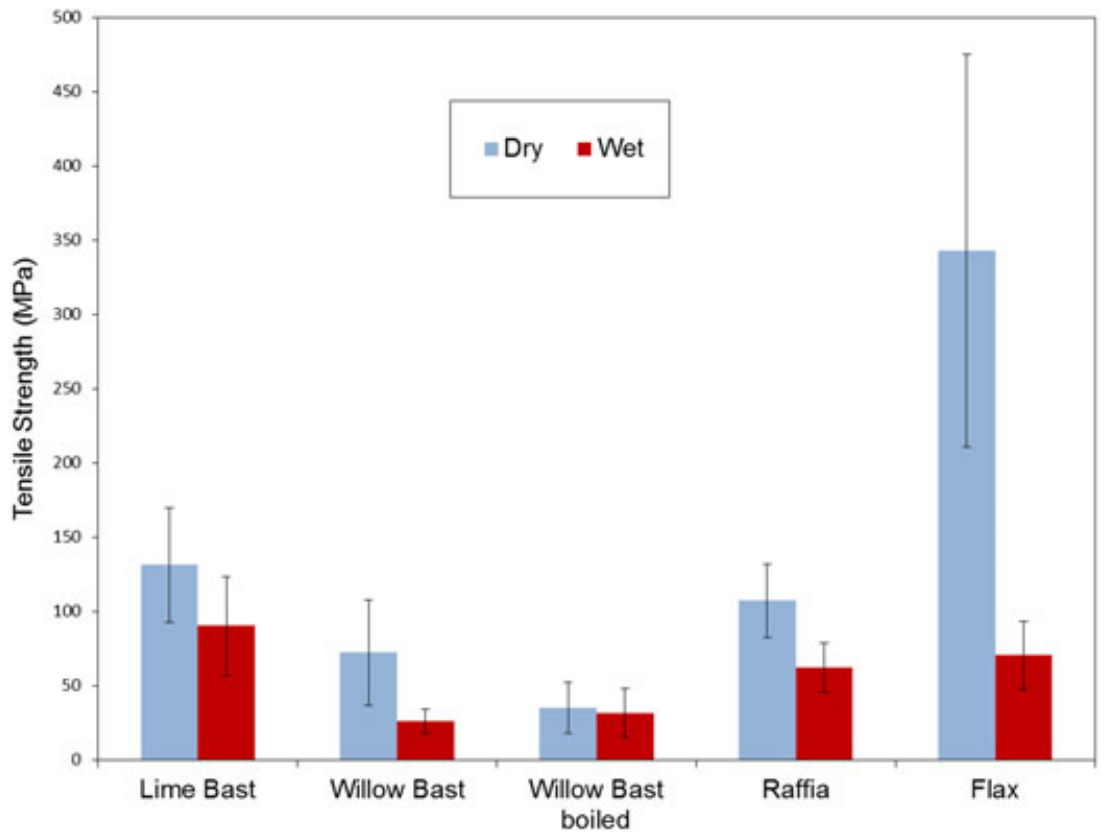

Figure 4 A comparison of the ultimate tensile strength for the different fibres tested in 'dry' and 'wet' conditions. 


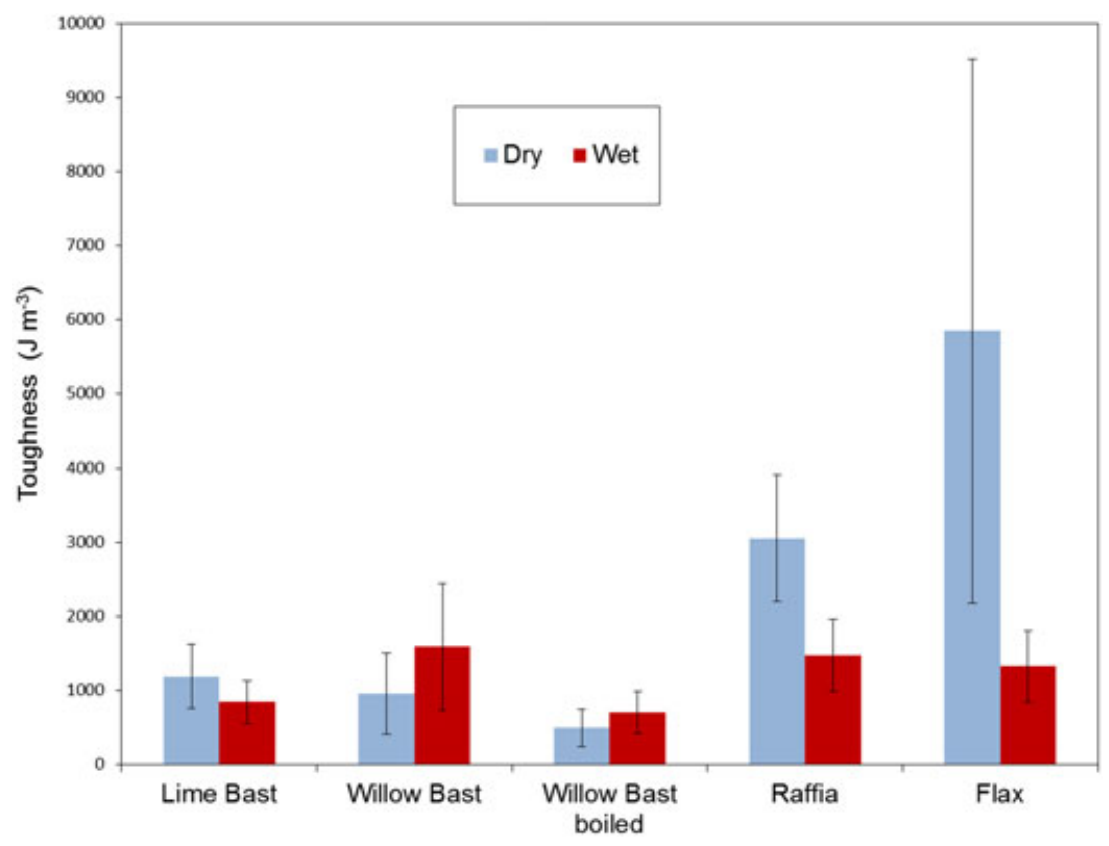

Figure 5 A comparison of the toughness for the different fibres tested in 'dry' and 'wet' conditions.

the stiffness decreases dramatically for wet flax, which has a far lower modulus of just $3 \mathrm{GPa}$ and so is more easily deformed; that is, flexed. Indeed, all the fibre strips appear less stiff when wet, and so are more easily deformed in the wet condition. Boiled willow bast fibre strips show the smallest stiffness variations for the wet and dry conditions, with both giving Young's modulus values of less than $2 \mathrm{GPa}$.

\section{Fibre strip tensile strength}

Figure 4 shows the ultimate tensile strength measured for each of the fibre strips and the trends observed are similar to those seen for Young's modulus. Dry flax has by far the greatest tensile strength at $350 \mathrm{MPa}$, but this value decreases significantly for wet flax, which has an ultimate tensile strength that is similar to the wet and dry values for the other natural fibre strips considered here. The other fibre strips also show lower tensile strengths when wet compared to when dry, with the exception of boiled willow bast, which has a similar low strength in both wet and dry conditions.

\section{Fibre strip toughness}

The toughness results for the fibre strips are shown in Figure 5. Some of the error bars for these measurements are relatively large; however, we can still draw some useful information from this figure. Dry flax produces the toughest fibre strips, with a lower toughness when wet. Lime bast has similar toughness wet and dry. Raffia is tougher in the dry condition, whereas the two willow basts appear to have slightly greater toughness in the wet condition. In combination with the results for Young's modulus, we can say that most of the plant fibre strips are both more pliable and weaker when wet, meaning that they cannot be treated roughly when wet. 


\section{Comparison with published observations}

The results for dry flax are in agreement with the mechanical properties described in the textile industry literature, where flax is described as 'stronger than cotton, but it is also more brittle and less flexible' (Hencken Elsasser 2010, 52). Comparing all fibre strips by looking at the tensile strength error bars, the results show that no fibre strips were stronger when wet; indeed, three (flax, willow bast and raffia) are significantly weaker. This is in contrast to the properties of flax and more generally cellulose fibre strips that are often cited in the literature as increasing in strength through wetting (Kornreich 1952, 16, fig. 8; Collier and Tortora 2001, 83; Hencken Elsasser 2010, 52). Tests on a cord of lime bast have also claimed that it was stronger when wet (Troset and Aunrønning 2003, in Myking et al. 2005, 70). This is contrary to the results presented here and may be due to several factors. In the literature sources, it is often unclear if it was individual fibres, fibre bundles or fibre strips that were being tested, or for how long the wet samples were soaked, which may affect the way in which they fracture. In this experiment we tested fibre strips, whereas it is typical within the textiles industry, from which most results originate, to test single fibres. The discrepancy may also be due to the way in which the results and errors are expressed and interpreted. For example, figures for the breaking tenacity of flax standard and wet (Collier and Tortora 2001, table $2.4,59$ ) are expressed as a specific strength (grams per dernier), but it is not stated if both measures are calculated on a dry basis; further, the stated ranges overlap. Thus, whereas Collier and Tortora consider the flax to be stronger when wet (Collier and Tortora 2001, 83), the conditions for which this statement holds are probably different from those applied in this study.

Across all the tests, wet fibre strips are typically less stiff and less brittle under a given load. In practice, this means that fibre strips will be more pliable and easier to work wet than dry. These results fit with the experience of spinning these fibre strips, which are easier to work when wet. However, the fibre strips are also weaker when wet, which means that they need to be handled more carefully. The brittleness of dry flax is noted elsewhere (Collier et al. 2009, 77) and is apparent in the results presented here. This means that dry flax will feel stiffer than either lime or willow, as flax fibres resist deformation. As the results for flax show, one of the weaknesses of flax is its brittleness, which could make it difficult to spin and weave fibres, yet this can be readily overcome simply by working the fibres while damp.

On the basis of these results, we return to the original question: did flax fibres provide early farmers with an especially good material that was superior to alternative fibres such as lime or willow bast? According to the results gained in this experiment, flax fibre strips wet or dry offered equally good or, in the case of dry strips, superior mechanical properties to fibre strips of lime and willow, as processed using the methods outlined in the materials section.

\section{DISCUSSION}

These results lead to two points of discussion: (1) evaluation of the experiment and potential developments; and (2) the contribution of the results to understanding the materials choices that people made in specific Mesolithic and Neolithic contexts.

\section{Evaluation of the experiment}

This experiment specified how the fibre strips were harvested and processed, and how the growing season, time of harvest and processing can affect the fibre properties. This is important because these may affect fibre properties. For example, if flax fibre is harvested when green and when the seed capsules are still forming, the fibres will be long and supple; if it is harvested 
too early, the fibres will be fine but weak; and when left to over-ripen, the flax fibres will be brittle (Médard 2005; Adugna 2012, 305). The increased lignification of late-harvested, coarse fibres adds to their strength. The flax in this study was harvested late for seed and this may in part account for the brittleness and high tensile strength. Studies of modern flax show variations in fibre tensile strength, as the genotype, soil, climate and agronomic practices influence the chemistry and structure of the cell walls, affecting the fibre properties (Norton et al. 2006, 15-16). In published tests on flax, the variety and season (year of harvest) were found to contribute to the strength of the fibres, while both fine and coarse fibres yielded high tensile strength (Norton et al. 2006, 22). Over-retting can cause loss of fibre quality (Adugna 2012, 305). In preparing lime bast for this experiment, it was noted that bast closest to the wood was finer and that closest to the bark was coarser; aspects that may affect the properties and require further study. It is reported that lime bast processed without retting may have double the breaking load (Myking et al. 2005, 70). Future tests could consider fibres retted for different lengths of time, processed using alternative methods, or from different areas of the branch or tree. In this experiment, the willow fibre strips were processed by two different methods (Table 1) and the differences in mechanical properties are slight, especially when compared with the results between species. Further tests are necessary to establish if the differences between species are greater than the differences between fibre strips of the same species processed using different methods.

Due to selective breeding, it remains questionable whether modern flax fibres are similar to those used in the past, or indeed are different from the wild flax (Abbo et al. 2014). It seems likely that lime and willow bast would be the same as those available today. This initial project seeks to test the major differences between the fibre strips obtained from flax, lime and willow. It would be desirable to carry out further tests on fibres processed using different means and a wider range of species.

\section{Material choices}

Processed flax fibre is physically finer than tree bast and hence easier to work into fine threads (Rast-Eicher 1997, 311). In the Neolithic dwellings of the Circum-Alpine area, for example, tree bast fibres were used for cords (1-3 mm diameter) and thick cords (over $3 \mathrm{~mm}$ diameter) and only rarely finer threads (less than $1 \mathrm{~mm}$ diameter), and were mostly used for twined textiles (Fig. 2 (a)); in contrast, flax fibre was mainly used for fine threads of less than $1 \mathrm{~mm}$ in diameter and was mostly used for woven textiles (Médard 2003, 80-3; Médard 2012, 368) (Fig. 2 (b)). That flax was more commonly used for fine threads and woven textiles suggests a relationship between the physical properties of the fibre, technology and product. Based on the mechanical tests presented here, the results for flax showed that when dry it is tougher and has a higher tensile strength than lime and both samples of willow. In terms of performance, this means that relative to the cross-sectional area, the dry flax strips tested required more force to break them and were better able to absorb shocks (energy) than either the lime or the willow. Flax may have been used for finer yarns because, in relation to the cross-sectional area, when dry it is stronger and tougher than lime or willow tree bast. Flax fibre may have been advantageous when used in fine, woven textiles, as it would produce a tougher, stronger material more able to resist tearing and breaking than tree bast. Fine textiles are time-consuming to make and this may have aided their longevity.

On the basis of data obtained in this experiment, dry flax offers some superior properties to the other fibres tested. Wet, however, the mechanical properties of flax were comparable to those of lime and willow bast. On this basis, the willow bast net used by the hunter-fishers of Antrea, Russia (Burov 1998, 61) may have been only slightly less efficient than one of flax. In the Late 
Neolithic lake dwellings, flax was the preferred material for nets (Rast-Eicher 1997, 311), with nets occasionally produced using tree bast-for example, at Wetzikon-Robenhausen, Switzerland (Altorfer and Médard 2000, 57-8) — and lime bast was used for the netting and cords used by the Late Neolithic Iceman (Pfeifer and Oeggl 2000; Putzer 2011, 33-5). We may assume that Mesolithic and Neolithic people gained experience of these performance characteristics through using nets when fishing and hunting.

Of the fibrous artefacts of the Neolithic Circum-Alpine area, tree bast fibre artefacts were more common those of flax (Médard 2010, 71-3, 107; Médard 2012, 368). This shows that despite the potentially impressive mechanical properties of dry flax, in quantity tree bast fibres remained the key fibre. This may be due to several reasons. Tree bast fibres are a woodland resource, which do not require farmland and can be foraged or managed through coppicing (Harris 2014, 5). However, early farmers applied their cultivation skills to grow flax for fibre. Although Allaby et al. (2005) argue that flax was domesticated for its oil, once domesticated, the dual crop of fibres and oil may have been part of its appeal. As fibres are needed in large quantities for all manner of string, textile and basketry uses, a range of fibres from across the landscape may have been an important strategy for materials acquisition during the Mesolithic and Neolithic.

\section{CONCLUSION}

To question why early farmers grew flax as a fibre crop from a materials perspective opens up a new and compelling direction of research. In this experiment, we provide results for the mechanical properties of flax, lime bast and willow bast fibre strips processed according to the methods described; through identification of archaeological material, these plant fibres are known to have been used by people in the Neolithic in certain areas of Europe. The results obtained in this experiment demonstrate that under dry conditions and in comparison to lime and willow, flax has good performance characteristics, as it is stronger and tougher. When wet, the mechanical properties of flax are less distinguishable from those of the other fibre strips tested. It seems in part that a farmer's motivation to grow flax could have been to gain fine fibres that were superior in some aspects to those available from two indigenous fibre species: lime and willow. However, the mechanical properties must be considered along with other material properties and as just one of many material (aesthetic, fineness, sensory appeal) and technological (production, availability) choices in the decision to use a fibre. This raises important issues in the motivations for farmers to prepare land, sow, tend and harvest a flax crop. Fibres are key resources and their properties are important aspects of such a resource.

The results of this initial project show a promising line of investigation to understand the Mesolithic-Neolithic transition from a materials perspective, and the choices that this engenders. In the future, it would be desirable to undertake further tests on species such as oak and poplar bast, which were also used in this period. In addition, it would be relevant to increase the number of tests on samples of the same species, and test fibres processed according to different methods and grown in various climatic conditions.

\section{ACKNOWLEDGEMENTS}

This research was supported by the Nuffield Foundation Science Bursaries Scheme, which funded Zunaira Dara at the School of Materials, Manchester University; a British Academy post-doctoral fellowship 'Cloth Cultures of Prehistoric Europe', awarded to Susanna Harris at the Institute of Archaeology, UCL; and the Marie Curie Action COFUND: PCOFUND- 
GA-2010-267228 at TOPOI Excellence Cluster, Freie Universität, Berlin, which funded the presentation of results at EAA2012. We thank Sue College and Sabine Karg for advice on fibres, Ian Freestone and Margarita Gleba for commenting on a draft, Pippa White for proof reading, Urs Leuzinger, South Tyrol Museum of Archaeology for image permissions; Lea Valley Regional Park, Stoke Newington Parish Church, Abney Park Cemetery, Flax Farm West Sussex, Vera Beining, Robin Bonner, Bill Sillar and students on the Experimental Archaeology course, UCL for fibres and fibre processing.

\section{REFERENCES}

Abbo, S., Zezak, I., Lev-Yadun, S., Shamir, O., Friedman, T., and Gopher, A., 2014, Harvesting wild flax in the Galilee, Israel and extracting fibers-bearing on Near Eastern plant domestication, Israel Journal of Plant Sciences, 62(1-2), $1-13$.

Adugna, W., 2012, in Linum usitatissiumum L., in Fibres (eds. M. Brink and E. G. Achigan-Dako), 299-306, PROTA Foundation/CTA, Wageningen, the Netherlands.

Airoldi, G., 2000, Il tessuto ordito e trama AD intreccio ortogonale, Centrocot S.p.A, Editore, Lipomo (Como).

Allaby, R. G., Peterson, G. W., Merriwether, D. A., and Fu, Y.-B., 2005, Evidence of the domestication history of flax (Linum usitatissimum L.) from genetic diversity of the sad2 locus, Theoretical and Applied Genetics, 112, 58-65.

Altorfer, K., and Médard, F., 2000, Nouvelles découvertes textiles sur le site de Wetzikon-Robenhausen (Zürich, Suisse): sondages 1999, in Archéologie des textiles des origines au V siècle, actes du colloque de Lattes, octobre 1999 (eds. D. Cardon and M. Feugère), 35-75, Èditions Monique Mergoil, Montagnac.

Andersen, S. H., 2013, Tybrind Vig: submerged Mesolithic settlements in Denmark, Moesgård Museum, Jutland Archaeological Society, Højbjerg.

Barber, E. J. W., 1991, Prehistoric textiles: the development of cloth in the Neolithic and Bronze Age with special reference to the Aegean, Princeton University Press, Princeton, NJ.

Barker, G., 2006, The agricultural revolution in prehistory: why did foragers become farmers? Oxford University Press, Oxford.

Bazzanella, M., and Mayr, A., 2009, I reperti tessili, le fusaiole e i pesi da telaio dalla palafitta di Molina di Ledro, Guinta della Provincia Autonoma di Trento, Soprintendenza per i Beni Librari, Archivistici e Archeologici, Trento.

Bazzanella, M., Mayr, A., Moser, L., and Rast-Eicher, A., 2003, Textiles: intrecci e tessuti dalla preistoria europea, Catalogo della Mostra, Museo Civico di Riva del Garda la Rocca, 24 maggio - 19 ottobre 2003, Provincia Autonoma di Trento, Servizio Beni Culturali, Ufficio Beni Archeologici, Trento.

Bender Jørgensen, L., 1990, Stone Age textiles in Northern Europe, in Textiles in Northern archaeology. NESAT III: textile symposium in York, 6-9th May 1987 (eds. P. Walton and J.-P. Wild), 1-10, Archetype, London.

Bergfjord, C., Karg, S., Rast-Eicher, A., Nosch, M.-L., Mannering, U., Allaby, R. G., Murphy, B. M., and Holst, B., 2010, Comment on '30,000-year-old wild flax fibers', Science, 328(5986), 1634.

Bergfjord, C., Mannering, U., Frei, K. M., Gleba, M., Scharff, A. B., Skals, I., Heinemeier, J., Nosch, M.-L., and Holst, B., 2012, Nettle as a distinct Bronze Age textile plant, Scientific Reports, 2, .article number 664

Bickle, P., and Whittle, A., 2014, Introduction: integrated and multi-scalar approaches to early farmers in Europe, in Early farmers: the view from archaeology and science (eds. A. W. D. Whittle and P. Bickle), 1-19, Published for The British Academy by Oxford University Press, Oxford.

Bodros, E., and Baley, C., 2008, Study of the tensile properties of stinging nettle fibres (Urtica dioica), Materials Letters, 62, 2143-2145.

Burov, G. M., 1998, The use of vegetable materials in the Mesolithic of Northeast Europe, in Harvesting the sea, farming the forest: the emergence of Neolithic societies in the Baltic region (eds. M. Zvelebil, L. Domanska, and R. Dennell), 53-63, Sheffield Academic Press, Sheffield.

Collier, B., and Tortora, P., 2001, Understanding textiles, 6th edn, Prentice Hall, Upper Saddle River, NJ.

Collier, B. J., Bide, M. J., and Tortora, P. G., 2009, Understanding textiles, 7th edn, Pearson Prentice Hall, Upper Saddle River, NJ.

Crawford, M., 2005, Lime bast cordage in Northen Europe, Agroforestry News, 13(3), 5-7.

Dimbleby, G. W., 1978, Plants and archeology, Humanities Press, Atlantic Highlands, NJ.

Farke, H., 1991, Schnüre Geflechte und Leder aus Höhlen bei Bad Frankenhausen, Alt-Thüringen, 26, 123-140.

Gleba, M., and Mannering, U. (eds.), 2012, Textiles and textile production in Europe: From prehistory to AD 400, Oxbow Books, Oxford. 
Greaves, P. H., and Saville, B. P., 1995, Microscopy of textile fibres, BIOS Scientific in association with the Royal Microscopical Society, Oxford.

Granlund, J., 1943-4, Lindbast och träbast, Folkliv, VII-VIII, 166-99 (English summary pp. 198-9).

Greig, J. R. A., 1982, Past and present lime woods of Europe, in Archaeological aspects of woodland ecology (eds. S. Limbrey and M. Bell), 23-55, BAR International Series, S146. British Archaeological Reports, Oxford.

Hanssen, O., and Lundestad, J., 1932, Lindebast og bastetog, Nyt Magazin for Naturvidensk (Kristiana), 71, $373-406$. English summary pp. 403-4.

Hardy, K., 2008, Prehistoric string theory. How twisted fibres helped to shape the world, Antiquity, 82, 271-280.

Harris, S., 2010, Smooth and cool, or warm and soft; investigating the properties of cloth in prehistory, in North European Symposium for Archaeological Textiles X (eds. E. B. Andersson Strand, M. Gleba, U. Mannering, C. Munkholt, and M. Ringgard), 104-112, Vol. 5, Oxbow Books, Oxford.

Harris, S., 2014, Flax fibre; innovation and change in the Early Neolithic - a technological and material perspective, in New directions: examining the past, creating the future, Los Angeles. Textile Society of America Biennial Symposium 2014 Proceedings (ed. A. Svenson), University of Nebraska Digital Commons.

Harris, S., and Gleba, M., 2015, Bronze Age moss fibre garments from Scotland-the jury's out, Archaeological Textiles Review, 57, 3-11.

Hencken Elsasser, V., 2010, Textiles; concepts and principles, 3rd edn, Fairchild Books, New York.

Herbig, C., and Maier, U., 2011, Flax for oil or fibre? Morphometric analysis of flax seeds and new aspects of flax cultivation in Late Neolithic wetland settlements in southwest Germany, Vegetation History and Archaeobotany, 20 (6), 527-533.

Hodges, H., 1995, Artifacts: an introduction to early materials and technology, 2nd edn, Duckworth, London.

Hurcombe, L., 2007, Archaeological artefacts as material culture, Routledge, London.

Hurcombe, L., 2014, Perishable material culture in prehistory: investigating the missing majority, Routledge, London. Ingold, T., 2007, Materials against materiality, Archaeological Dialogues, 4(1), 1-16.

Jarman, C., 1998, Small-scale textiles: plant fibre processing, Intermediate Technology Publications, London.

Jones, A., 2004, Archaeometry and materiality: materials-based analysis in theory and practice, Archaeometry, 46, 327-338.

Karg, S., 2011a, New research on the cultural history of the useful plant Linum usitatissimum L. (flax), a resource for food and textiles for 8,000 years, Vegetation History and Archaeobotany, 20(6), 507-508.

Karg, S. (ed.), 2011b, Special issue: FLAX — new research on the cultural history of the useful plant Linum usitatissimum L., Vegetation History and Archaeobotany, 20(6).

Körber-Grohne, U., and Feldtkeller, A., 1998, Pflanzliche Rohmaterialien und Herstellungstechniken der Gewebe, Netze, Geflechte sowie anderer Produkte aus den neolithischen Siedlungen Hornstaad, Wangen, Allensbach und Sipplingen am Bodensee, in Siedlungsarchäologie im Alpenvorland V, 131-189, Konrad Theiss Verlag, Stuttgart.

Kornreich, E., 1952, Introduction to fibres and fabrics, their manufacture and properties, National Trade Press, London.

Kvavadze, E., Bar-Yosef, O., Belfer-Cohen, A., Boaretto, E., Jakeli, N., Matskevich, Z., and Meshveliani, T., 2009, 30,000-year-old wild flax fibres, Science, 325, 1359.

Leuzinger, U., 2002, Textilherstellung, in Die jungsteinzeitliche Seeufersiedlung Arbon-Bleiche 3: Funde, Archäologie im Thurgau 11 (eds. A. de Capitani, S. Deschler-Erb, U. Leuzinger, E. Marti-Grädel, and J. Schibler), 115-134, 11th edn, Departement für Erziehung und Kultur des Kantons Thurgau, Frauenfeld.

Leuzinger, U., and Rast-Eicher, A., 2011, Flax processing in the Neolithic and Bronze Age pile-dwelling settlements of eastern Switzerland, Vegetation History and Archaeobotany, 20(6), 535-542.

Lozovskaya, O. V., Lozovski, V. M., Mazurkevich, A. N., Clemente Conte, I., and Gassiot, Е., 2012, Дерев янные конструкции на стоянке каменного века Замостье 2: новые данные, М. Языки славянской культуры, 250-9, КСИА, №227 [Wooden objects from the prehistoric site of Zamostje 2; new information, in Languages of the Slavic cultures, 250-9, KSIA 227 (English summary p. 250)].

Lucas, G., 2012, Understanding the archaeological record, Cambridge University Press, New York.

McGrail, S., 2014, Ancient boats in north-west Europe: the archaeology of water transport to AD1500, Routledge, Abingdon.

Maier, U., and Schlichtherle, H., 2011, Flax cultivation and textile production in Neolithic wetland settlements on Lake Constance and in Upper Swabia (south-west Germany), Vegetation History and Archaeobotany, 20(6), 567-578.

Martial, E., and Médard, F., 2007, Acquisition et traitement des matières textiles d'origine végétale en Préhistoire: l'exemple du lin, in Plant processing from a prehistoric and ethnographic perspective / Préhistoire et ethnographie du travail des plantes. Proceedings of a workshop at Ghent University (Belgium) November 28, 2006 (eds. V. Beugnier and P. Crombé), 67-82, BAR International Series, 1718, Archaeopress, Oxford. 
Médard, F., 2003, La produzione di filo nei siti lacustri del Neolitico, in Textiles: intrecci e tessuti dalla preistoria europea (eds. M. Bazzanella, A. Mayr, L. Moser, and A. Rast-Eicher), 79-86, Provincia Autonoma di Trento, Sevizio Beni Culturali, Ufficio Beni Archeologici, Trento.

Médard, F., 2005, Préparation et transformation du lin destiné à la production des fins extrêmement fins: donnés archéologiques, anatomiques et expérimentales, Bulletin de liaison du CIETA, 82, 6-24.

Médard, F., 2010, L'art du tissage au néolithique: IV -III millénaires avant J.-C. en Suisse, CNRS, Paris.

Médard, F., 2012, Switzerland: Neolithic period, in Textiles \& textile production in Europe: from prehistory to AD 400 (eds. M. Gleba and U. Mannering), 367-377, Oxbow Books, Oxford.

Myking, T., Hertzberg, A., and Skrøppa, T., 2005, History, manufacture and properties of lime bast cordage in Northern Europe, Forestry, 78(1), 65-71.

Needles, H. L., 1981, Handbook of textile fibres, dyes, and finishes, Garland, New York.

Norton, A. J., Bennett, S. J., Hughes, M., Dimmock, J. P. R. E., Wright, D., Newman, G., Harris, I. M., and Edwards-Jones, G., 2006, Determining the physical properties of flax fibre for industrial applications: the influence of agronomic practice, Annals of Applied Biology, 149(1), 15-25. DOI: 10.1111/j.17447348.2006.00066.x.

Pfeifer, K., and Oeggl, K., 2000, Analysis of the bast used by the Iceman as binding material, in The man in the ice, vol. 4: The Iceman and his natural environment: palaeobotanical results (eds. S. Bortenschlager and K. Oeggl), 69-76, Springer-Verlag, Wien.

Pigott, D., 2012, Lime-trees and basswoods: a biological monograph of the genus Tilia, Cambridge University Press, Cambridge.

Puliti, M., 1987, Le fibre tessili naturali-artificiali-sintetiche: nozioni elementari ad uso degli Istituti Statali d'Arte, Istituto Statale d'arte di Firenze, Firenze.

Putzer, A., 2011, L'uomo dei Ghiacchi e il suo equipaggiamento, in Ötzi 2.0: una mummia tra scienza e mito (ed. A. Fleckinger), 22-43, Folio Editore, Vienna/Bolzano.

Rast-Eicher, A., 1997, Die Textilien, in Ökonomie und Ökologie neolithischer und bronzezeitlicher Ufersiedlungen am Zürichsee: Ergebnisse der Ausgrabungen Mozartstrasse, Kanalisationssanierung Seefeld, AKAD/Pressehaus und Mythenschloss in Zürich. Band A, Text (eds. J. Schibler, H. Hüster-Plogmann, S. Jacomet, C. Brombacher, E. Gross-Klee, and A. Rast-Eicher), 300-328, Direktion der Öffentlichen Bauten des Kantons Zürich, Hochbauamt, Abt. Kantonsarchäologie, Zürich.

Rast-Eicher, A., 2005, Bast before wool: the first textiles, in Hallstatt textiles: technical analysis, scientific investigation and experiments on Iron Age textiles (eds. P. Bichler et al.), 117-131, Archaeopress, Oxford.

Rast-Eicher, A., and Thijsser, S., 2001, Anbau und Verarbeitung von Lein: Experiment und archäologisches Material, Zeitschrift für Schweizerische Archäologie und Kunstgeschichte, 58(1), 47-56.

Reichert, A., 2000, Rotten oder Rösten von Lindenbast? AEAS/GAES Anzeiger, 2000, 1-4.

Reichert, A., 2007, Bast, rushes, stinging nettles. Textile materials from the Stone Age. Archaeological reconstructions by Anne Reichert, Museum für Archäologie und Ökologie Dithmarschen, http://www.museum-albersdorf.de/bast/ annecatalogenglish.pdf (accessed 9 May 2011).

Reichert, A., 2011, Bast, Binsen, Brennnessel: textiles Material der Steinzeit. Alle Poster der Sonderausstellung mit archäologischen Rekonstruktionen von Anne Reichert. http://www.museum-albersdorf.de/bast/ (accessed 9 August 2016).

Reichert, A., 2013, Textile techniques of the Stone Ages, in Ancient textiles, modern science: re-creating techniques through experiment: proceedings of the First and Second European Textile Forum 2009 and 2010 (ed. H. Hopkins), 79-101, Oxbow Books, Oxford.

Robinson, E., Hadjikoumis, A., and Viner, S., 2011, Introduction: the dynamics of Neolithisation in Europe, in The dynamics of Neolithisation in Europe: studies in honour of Andrew Sherratt (eds. A. Hadjikoumis, E. Robinson, and S. Viner), 1-9, Oxbow Books, Oxford.

Saville, B. P., 1999, Physical testing of textiles, Woodhead Publishing in association with The Textile, Institute, Cambridge.

Schick, T., 1988, Nahal Hemar Cave_cordage, basketry and fabrics, Atiqot, 18, 31-43.

Sillar, B., and Tite, M.S., 2000, The challenge of "Technological Choices" for materials science approaches in archaeology. Archaeometry, 42(1), 2-20.

Troset, J., and Aunrønning, O., 2003, Testrapport for bruddstyrke og bruddforlengelse i $12 \mathrm{~mm}$ lindebasttau, Norwegian University of Science and Technology (NTNU), Department of Structural Engineering, Trondheim.

Van Gijn, A., 2010, Flint in focus, lithic biographies in the Neolithic and Bronze Age, Sidestone Press, Leiden.

Warnford Lock, C. G., and Stab, S., 1880, Notes on some neglected fibres, Journal of the Society for Arts, 28(1460), 915-920. 
Wood, J., 2011, Daily practices of prehistoric Europe during the Mesolithic/Neolithic transition, in Experiments with past materialities (eds. D. Gheorghiu and G. Children), 9-17, Archaeopress, Oxford.

Wulfhorst, B., 2001, Processi di lavorazione dei prodotti tessili, Italian edn, Tecniche Nuové, Milano.

Zohary, D., Hopf, M., and Weiss, E., 2012, Domestication of plants in the Old World: the origin and spread of domesticated plants in South-West Asia, Europe, and the Mediterranean Basin, 4th edn, Oxford University Press, Oxford.

\section{SUPPORTING INFORMATION}

Additional Supplementary material may be found in the online version of this paper on the publisher's website. 